\title{
Med to spiraler i uterus
}
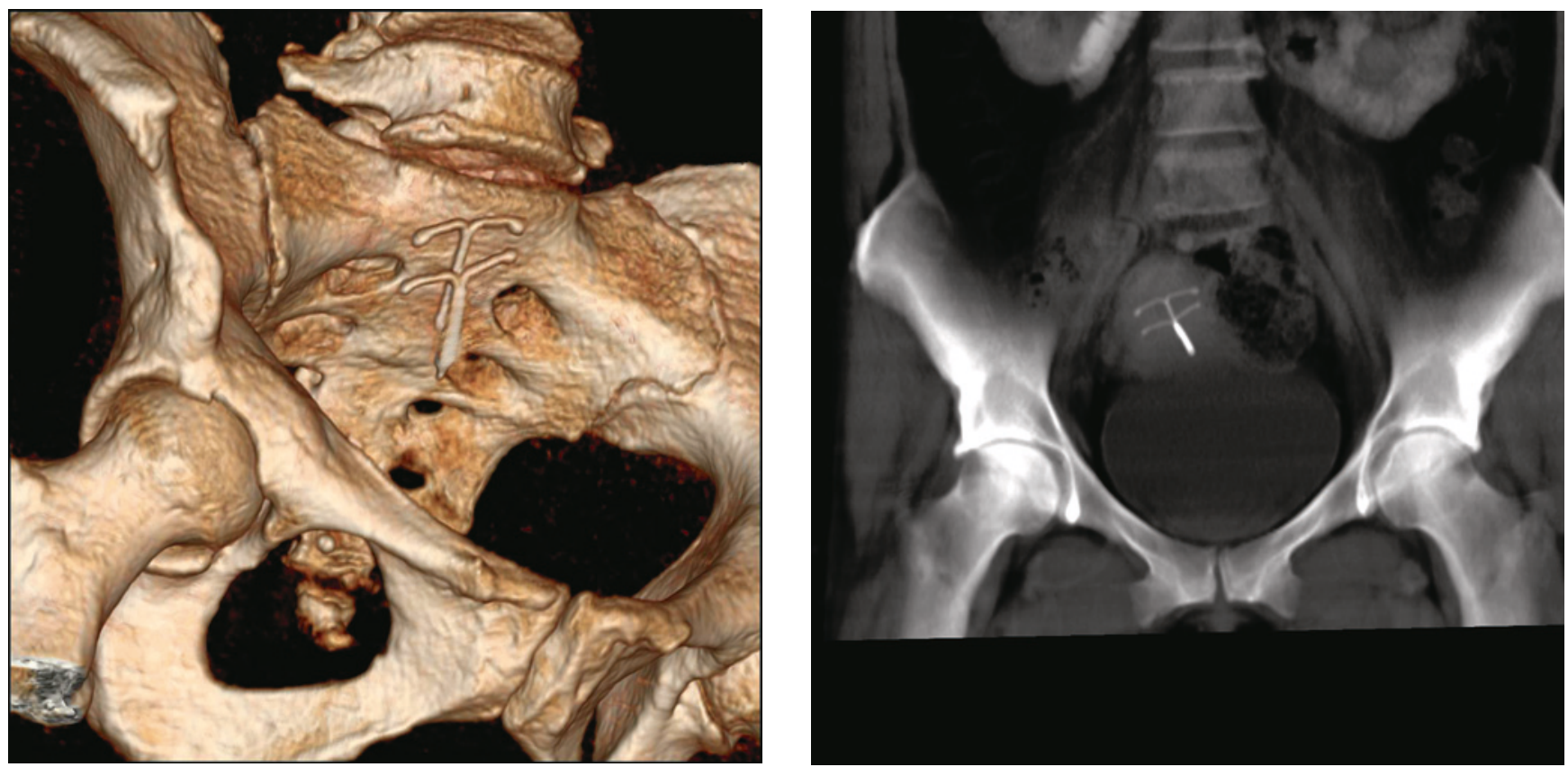

En kvinne i slutten av 40-årene ble innlagt på kirurgisk avdeling grunnet magesmerter. Standard CT-undersøkelse av abdomen/ bekken viste ingen årsak til pasientens smerter, men som bifunn ble det påvist to spiraler i uterinkaviteten, her presentert som 3Drekonstruksjon (bildet til venstre) og tykk multiplanrekonstruksjon (bildet til høyre) av CT-opptaket. Ved søk på PubMed finner vi bare ett liknende rapportert tilfelle av to spiraler i uterus (1).

Pasienten ble henvist til gynekologisk poliklinikk for uthenting av spiralene. Ved transvaginal ultralyd verifiserte man to spiraler. Den ene, en hormonspiral, var enkel å fjerne, da trådene var synlige ved cervix. Trådene til den andre spiralen, som var en kobberspiral, ble funnet et stykke opp i cervixkanalen. Spiralen ble fjernet ukomplisert.

Kobberspiralen ble satt inn av allmennlege etter siste fødsel, omtrent 20 år før det aktuelle. Hormonspiralen ble satt inn noen år senere, trolig ved et annet legekontor. Kobberspiralen må på dette tidspunkt ha vært antatt utstøtt. Hormonspiral ble skiftet på gynekologisk poliklinikk to ganger senere, sist fem år før det aktuelle. Av journalen fremgår det at spiral ble visualisert på plass i uterus med transvaginal ultralyd ved begge anledninger. Hormonspiraler kan være vanskelig å se ved ultralyd. Vi må anta at det man har oppfattet som ekkoskygge fra hormonspiralen i minst like stor grad har vært skygge fra kobberspiralen.

Noen kvinner får innsatt spiral i løpet av ammeperiodens amenoré. På dette tidspunkt er uterus liten pga. manglende østrogenstimulering. Om trådene klippes for kort, vil de forsvinne opp i cervixkanalen når uterus gjenvinner normal størrelse. Dette har trolig vært tilfellet med vår pasient. Et viktig poeng er derfor å klippe trådene lange hvis menstruasjonssyklus ikke er gjenetablert.

Dersom det ved innsetting av spiral er usikkert om det allerede er en spiral der, må dette avklares med ultralyd. Hvis en tidligere innsatt spiral ikke gjenfinnes ved inspeksjon (tråder) eller ultralyd, og kvinnen ikke har sett tegn til utstøtning, må annen bildediagnostikk overveies.

Pasienten har gitt samtykke til at artikkelen blir publisert.

\section{Kristian Kolnes}

kristian.kolnes@gmail.com

Sverre B. Sundalsfoll

Bo Jacobsson
Kristian Kolnes (f. 1967) er spesialist i radiologi, overlege og konstituert seksjonsleder ved Radiologisk avdeling, Volda sjukehus Forfatter har fylt ut ICMJE-skjemaet og oppgir ingen interessekonflikter.

Sverre B. Sundalsfoll (f. 1944) er spesialist i radiologi og overlege ved Radiologisk avdeling. Volda sjukehus.

Forfatter har fylt ut ICMJE-skjemaet og oppgir ingen interessekonflikter.

Bo Jacobsson (f. 1960) er spesialist i fødselshjelp og kvinnesykdommer, overlege og leder av Fetal medicinska enheten ved Sahlgrenska Universitetssjukhuset, Göteborg. Han er professor ved Sahlgrenska Akademin, Göteborgs Universitet og seniorforsker ved Folkehelseinstituttet, Oslo.

Forfatter har fylt ut ICMJE-skjemaet og oppgir ingen interessekonflikter.

\section{Litteratur}

1. Moustafa M. Two intrauterine contraceptive devices. J Obstet Gynaecol 2008; 28: 112-3.

Mottatt 4.11. 2013, første revisjon innsendt 17.4 2014, godkjent 15.6. 2014. Redaktør: Matilde Risopatron Berg. 